\title{
Monochlorinated calocerins A-D and 9-oxostrobilurin derivatives from the basidiomycete Favolaschia calocera
}

Clara Chepkirui ${ }^{[a]}$, Christian Richter ${ }^{[a]}$, Josphat Clement Matasyoh ${ }^{[b]}$ and Marc Stadler ${ }^{[a] *}$

${ }^{a}$ Helmholtz Centre for Infection Research GmbH (HZI), Department Microbial Drugs, Inhoffenstraße 7, 38124 Braunschweig, Germany.

${ }^{b}$ Egerton University, Department of Chemistry, P.O BOX 536, 20115, Njoro, Kenya.

*Corresponding author: Marc Stadler, e-mail: marc.stadler@helmholtz-hzi.de, phone: +49 531 6181-4240, fax: 49531 6181-9499 


\begin{abstract}
Eight previously undescribed compounds were isolated and characterised from the supernatant and mycelium of a culture of the basidiomycete Favolaschia calocera originating from Kakamega equatorial rainforest in Kenya. These were: 9- oxostrobilurins A, G, K and I and the four monochlorinated calocerins A, B, C and D. The calocerins extend our knowledge of halogenated compounds obtained from natural sources. Four further known compounds were also identified: strobilurin $\mathrm{G}$, favolon, pterulinic acid and 2,3 -dihydro-1-benzoxepin derivative. The four oxostrobilurins exhibited prominent antifungal and cytotoxic activities while the four calocerins only showed cytotoxic activity.

Key words: Favolaschia calocera, Mycenaceae, structure elucidation, strobilurins, calocerin, antifungal activity, cytotoxicity.
\end{abstract}




\section{Introduction}

Fungi are one of the most diverse groups of organisms with tropical regions considered to harbour most of their species (Hawksworth, 2001). The Basidiomycota in particular are known to be rich in unique bioactive metabolites but many of their species have not been studied extensively (Stadler and Hoffmeister, 2015). Important medicinal mushrooms like Agaricus subrufescens, Ganoderma sichuanense, Grifola frondosa, Phellinus linteus, and Hericium erinaceus have been reported to possess a variety of therapeutic treatments (Da Sila et al., 2013; Richter et al., 2015; Thongbai et al., 2015). In recent years, exploitation of mushrooms in quest for novel metabolites with therapeutic properties has been on the rise, resulting in isolation of several bioactive compounds. These compounds include cyathins, striatins, sarcodonins, scabronines, chlorinated orcinols, erinacines, corallocins, laschiatrion and pleuromutilins with different biological activities such as antimicrobial, anti-inflammatory, antiproliferative, osteoclast-forming suppressing properties, nerve growth factor activating activities, or agonistic effects toward the kappa-opioid receptor (De Silva et al., 2013; Mudalungu et al., 2015; Stadler and Hoffmeister, 2015; Richter et al., 2016; Wittstein et al., 2016). While most of the aforementioned compounds were found from basidiomycetes of Asian, American and European origin the mycobiota of Africa remains largely untapped with regard to studies on their bioactive metabolites. In this paper we describe the isolation and identification of several novel molecules from a strain that was recently obtained and characterized in the course of a survey of Kenyan basidiomycetes that had shown pronounced biological activities in a preliminary screening for novel antifungal compounds. 


\section{Results and discussion}

Favolaschia calocera R. Heim (Mycenaceae) was identified to species level by sequencing parts of the rDNA (5.8S gene region, including the internal transcribed spacers (ITS1 and ITS2) and part of the large subunit LSU) as described in the Experimental. A BLAST search in GenBank confirmed the identity of the fungal culture as Favolaschia calocera, since the most homologous sequences were derived from this species.

This fungus was investigated for active secondary metabolites as its crude extract exhibited strong antifungal activity against Candida tenuis and Mucor plumbeus during antimicrobial screening. Chemical profiling of the supernatant and mycelium extracts led to the isolation of eight previously undescribed compounds: 9- oxostrobilurin A (1), 9-oxostrobilurins G (2), 9oxostrobilurins K (3), 9-oxostrobilurin I (4), calocerin A (5), calocerin B (6), calocerin C (7) and calocerin D (8). Four known compounds: strobilurin G, favolon, pterulinic acid and 2,3 dihydro-1-benzoxepin were also isolated (Anke et al., 1995; Engler et al., 1997; Fredenhagen et al., 1990; Kornsakulkarn et al., 2010).

From the supernatant extract, compound 1 (figure 1) was isolated as yellow oil. Its molecular formula was determined to be $\mathrm{C}_{16} \mathrm{H}_{18} \mathrm{O}_{4}$ from the HRMS. A doublet for methyl group proton ( $\delta$ 1.30), two methoxy groups singlets ( $\delta 3.73$ and 3.85) and aromatic protons signals were observed in the ${ }^{1} \mathrm{H}$ NMR (table 1$)$. $\mathrm{H}-15(\delta 3.85)$ showed correlation to $\mathrm{C}-12(\delta 160.2)$ while $\mathrm{H}-16(\delta 3.73)$ was correlating to $\mathrm{C}-13(\delta 167.9)$ in the HMBC spectra. Further, HMBC correlations observed between $\mathrm{H}-12$ to $\mathrm{C}-13 / \mathrm{C}-11 / \mathrm{C}-15 / \mathrm{C}-10$ suggested the presence of a $\beta$-methoxyacrylate moiety in the molecule. The methyl protons (H-14) occurring at $\delta 1.30$ showed HMBC correlation to C9/C-10/ C-11 as well as coupling constant $\mathrm{J}=6.87 \mathrm{~Hz}$ which was equivalent to that of the $\mathrm{C}-10$ proton implying that $\mathrm{C}-14$ and $\mathrm{C}-10$ were connected to each other. Furthermore, $\mathrm{H}-8(\delta 6.78)$ 
correlation to C-6 $(\delta 134.9) / \mathrm{C}-9(\delta 198.9)$ and $\mathrm{H}-7(\delta 7.78)$ correlations to $\mathrm{C}-1 / 5(\delta 128.2) / \mathrm{C}-8$ ( 8123.8$) /$ C-9 ( $\delta 198.9)$ in the HMBC established the connection of the side chain to the aromatic ring. Further, COSY correlation was observed between $\mathrm{H}-7$ and H-8. The olefinic bond between C-7 and C-8 was assigned as trans based on its coupling constant (16.02Hz). Compound $\mathbf{1}$ had been reported before as a semisynthetic derivative (Engler et al., 1999), but we report it for the first time as a natural product.

Compound $\mathbf{2}$ was isolated as yellow oil from both the supernatant and mycelium. Its molecular formula was established as $\mathrm{C}_{26} \mathrm{H}_{34} \mathrm{O}_{7}$ from HRMS. The NMR data indicated the presence of a 1,2,4-trisubstituted benzene ring and the same 9-oxostrobilurin side chain fragment as in (1). Correlations between diastereotopic protons $\mathrm{H}-18$ to $\mathrm{C}-3 / \mathrm{C}-20$ were observed in the $\mathrm{HMBC}$ spectra. Further, COSY correlations between the same protons and H-19 $(\delta 3.53)$ were observed. H-19 showed HMBC correlation to C-20,/C-21/ C-22/ C-23. The two methyl singlets H-21 and H-22 correlated to C-20 in the HMBC spectrum. Thus, a partial structure of the molecule was established as an isoprene unit. Moreover, NOESY correlations between $\mathrm{H}-21(\delta 1.26)$ to $\mathrm{H}_{\mathrm{a}}-18$ ( $\delta$ 4.07) and between $\mathrm{H}-22(\delta 1.47), \mathrm{H}_{\mathrm{b}}-18(\delta 4.28)$ and $\mathrm{H}-19$ (3.53) supported the presence of another isoprene unit fragment in the molecule. The NOE cross peak between H-19 and H-22 was observed, giving an indication of the stereochemistry at C-19. From the COSY correlation between $\mathrm{H}-23$ and $\mathrm{H}-24$ and HMBC correlations of the methyl protons $\mathrm{H}-26 / \mathrm{H}-27$ to $\mathrm{C}-24 / \mathrm{C}-25$ and the methylene proton $\mathrm{H}_{\mathrm{b}}-23$ to $\mathrm{C}-25$, the structure of the second isoprene unit fragment was deduced. A HMBC correlation of $\mathrm{H}-23$ to $\mathrm{C}-19$ confirmed the linkage of this side chain to the rest of the molecule. Oxygen atoms were proposed to attach the isoprene units based on C-18 $(\delta$ 68.9), C-20 ( $\delta 81.3)$ and C-23 ( $\delta 67.3)$ chemical shifts. The NMR data of the 1,5-benzodioxepin part of the molecule were in agreement with those of relevant fragment of the known compounds 
strobilurin G and 9-methoxystrobilurin G. (Fredenhagen et al., 1990; Hellwig et al., 1999; Kornsakulkarn et al., 2010).

Compound $\mathbf{3}$ was isolated as yellow oil from both the supernatant and the mycelium of the culture. Its molecular formula was established as $\mathrm{C}_{26} \mathrm{H}_{34} \mathrm{O}_{7}$ from HRMS. Subsequent examination of ${ }^{1} \mathrm{H}$ and ${ }^{13} \mathrm{C}$ data revealed close similarities with those of compound $\mathbf{2}$ with the main difference being on the 1,5-benzodioxepin side chain. All the 2D NMR correlations were similar to those of (2) accept for the side chain mention above. Compound $\mathbf{3}$ side chain had a quaternary carbon C23 ( $\delta 76.2$ ), two chemically equivalent methyl group C-26 and 27 ( $\delta 26.3)$ and vinyl carbons C24 ( $\delta 143.4)$ and exo-methylene group C-25 ( $\delta$ 114.5). The HMBC correlations of H-26/27 ( $\delta$ 1.31) to C-23/C-24, H-24 ( $\delta 5.9)$ to C-23/C-25/C-26/ C-27 as well as those of $\mathrm{H}-25$ ( $\delta 5.16)$ to C-23/C- 24 established an isoprene side chain linked to the C-19 ( $\delta 75.3)$ via an oxygen atom. This assignment was supported by the HMBC correlation of H-19 ( $\delta 3.68)$ to C-23. The NMR data of (3) were similar to those of the already reported strobilurin $\mathrm{K}$, the difference being the keto group at C-9 (Gillian et al., 1997).

Compound $\mathbf{4}$ was also obtained as a yellow oil from the supernatant and mycelium of the culture. Its molecular formula was determined as $\mathrm{C}_{21} \mathrm{H}_{36} \mathrm{O}_{7}$. Just like compound $\mathbf{2}$ and $\mathbf{3}$, the NMR data indicated the presence of 1,2,4-trisubstituted benzene ring and compound 1, 9-oxostrobilurin side chain fragment. Further, compound's 4 NMR data were in close agreement with those of compound $\mathbf{2}$ and $\mathbf{3}$ with the main difference being the absence of the second isoprene unit. The HMBC correlations between diastereotopic protons of C-18 to C-19/C-3/C-20 together with those of $\mathrm{H}-21 / \mathrm{H}-22$ to $\mathrm{C}-19 / \mathrm{C}-20$ confirmed the presence of the isoprene unit. The cross peaks in the NOESY spectra between H-21 ( $\delta 1.25)$ to Ha-18 $(\delta 4.13)$ and between $\mathrm{H}_{\mathrm{b}}-18(\delta$ 4.21), H-22 $(\delta 1.54)$ and $\mathrm{H}-19(\delta 3.63)$ supported the assignment of the isoprene unit fragment in the 
molecule. Based on the chemical shifts of C-18 ( $\delta 70.9 \mathrm{ppm})$ and C-20 (81.6 ppm), oxygen atoms were suggested as linkages to the benzene ring. The chemical shift of C-19 $(\delta 81.6)$ suggested an oxygenated carbon, thus the hydroxyl group was attached to this carbon.

To determine the stereochemistry at C-19, (4) was esterified with Mosher's acid (both S and R-2methoxy-2-penyl-2-(trifloromethyl) acetyl (MPA) chloride) in pyridine according to Hoye et al. (2007). The difference in chemical shifts $\left(\Delta \partial^{\mathrm{SR}}\right)$ between S and R-MTPA esters were used to assign the stereochemistry at the C-19 stereocenter. H-19, methyl protons of C-21 and C-22 showed positive values for $\Delta \partial^{\mathrm{SR}}=\partial$ (S-MTPA ester) $-\partial$ (R-MTPA ester) i.e. $+0.01,0.13$ and 0.08 respectively. The diastereotopic protons $\mathrm{H}_{\mathrm{a}}-18$ and $\mathrm{H}_{\mathrm{b}}-18$ on the other hand, gave negative values i.e. -0.12 and 0.02 respectively. Therefore, the methyl protons (H-21 and H-22) and H-19 are located on the same side of the plane, while the diastereotopic protons $\left(\mathrm{H}_{\mathrm{a}^{-}}-18\right.$ and $\left.\mathrm{H}_{\mathrm{b}}-18\right)$ are on the same side of plane. This was supported by the NOE cross peak between H-19 and H-22 (figure 2). Therefore, the absolutes stereochemistry of (4) at position 19 can be assigned as S. Similar results have been reported before for strobilurin I, with the S conformer of the MTPA ester being reported to have the minimum energy (Hellwig et al., 1999). Treatment of compound $\mathbf{3}$ with trifluoroacetic acid (TFA) cleaved the dimethylallyl side chain yielding 9-oxostrobilurin I which was identified from its ${ }^{1} \mathrm{H}$ and ${ }^{13} \mathrm{C}$ NMR data which were similar to those of compound 4. Esterification of this compound with both S and R MTPA chloride gave similar results as those observed for compound 4 , indicating the same $\mathrm{S}$ configuration for both compounds at C-19. Due to limited material the absolute configuration of compound 2 could not be determine. However, the NOESY, COSY and HMBC correlation were in agreement with those of compound $\mathbf{3}$ and $\mathbf{4}$ and, along with the fact that the compounds were obtained as congeners and are likely to be biosynthesised via the same pathway, might suggest 
similar S configuration at C-19.

Compound $\mathbf{5}$ and $\mathbf{6}$ were obtained as white solids. From the HRMS data, their molecular formula was determined as $\mathrm{C}_{12} \mathrm{H}_{10} \mathrm{ClNO}_{2}$. The presence of $[\mathrm{M}]^{+}$and $[\mathrm{M}+2]^{+}$peaks in the ESI-MS in the ratio 3:1 indicated the presence of a chlorine atom in these molecules. Signals for a methyl group, three protons of 1,2,4-trisubstituted benzene ring and 2 methine singlets were observed in their ${ }^{1} \mathrm{H}$ NMR. Further, absorption bands characteristic of an amide in the IR spectra of both compounds were observed $\left(3373,3175,1651 \mathrm{~cm}^{-1}\right)$. HMBC correlations from $\mathrm{H}-4 / \mathrm{H}-6$ to $\mathrm{C}-10$ revealed the position of the amide group. The presence of the furan ring was established based on the HMBC correlations of $\mathrm{H}-3$ to $\mathrm{C}-4 / \mathrm{C}-3 \mathrm{a} / \mathrm{C}-7 \mathrm{a} / \mathrm{C}-2 / \mathrm{C}-8$ and $\mathrm{H}-7$ to $\mathrm{C}-3 \mathrm{a} / \mathrm{C}-7 \mathrm{a}$. The side chain connection was determined from the HMBC correlation of $\mathrm{H}-9$ to $\mathrm{C}-2 / \mathrm{C}-8 / \mathrm{C}-11$ and $\mathrm{H}-11$ to $\mathrm{C}-$ 2/C-8/C-9. The chlorine atom was assigned to $\mathrm{C}-11$ based on the chemical shift $(\delta 115.8,119.8)$. NOESY correlations between H-9 to H-3/H-11 for compound 5 and H-3 to H-9 for compound 6 indicated a $Z$ - configuration and $E$-configuration of the olefinic bond for compound $\mathbf{5}$ and $\mathbf{6}$, respectively.

Compound 7 was isolated as white solid from the mycelial extract. $[\mathrm{M}]^{+}$and $[\mathrm{M}+2]^{+}$peaks in the ESI-MS in the ratio 3:1 were observed, indicating the presence of a chlorine atom in the molecule. Its molecular formula was deduced as $\mathrm{C}_{11} \mathrm{H}_{8} \mathrm{ClNO}_{3}$ from HRMS data. The doublet peak occurring at $\delta 7.64$ implied the presence of a 1,2,4-trisubstituted benzene ring. The position of the amide group was established from $\mathrm{H}-6 / \mathrm{H}-8$ to $\mathrm{C}-11 \mathrm{HMBC}$ correlations. $\mathrm{HMBC}$ correlations of H-9 to C-9a/5a, H-5 to C-6/C-4/C-9a and H-4 to C-5/ C-5a /C-2 suggested the presence of a benzoxepin ring. A cross peak was observed in the COSY spectra for $\mathrm{H}-4$ and H-5. The second oxygen was included in the ring based on the chemical shifts of C-4 ( $\delta$ 142.3) and C-2 ( $\delta 152.9)$. The $\mathrm{C}-2$ to the alkene chain linkage was assigned from the $\mathrm{HMBC}$ correlation of $\mathrm{H}-10$ to $\mathrm{C}-2$. 
Finally, based on the chemical shift, the chlorine atom was assigned to C-10. Interestingly, this compound has an unique and novel structure with two oxygen atoms in the benzoxepin ring, which normally has six carbon atoms.

Compound $\mathbf{8}$, which is closely related to compound $\mathbf{7}$, was isolated as white solid with a molecular formula of $\mathrm{C}_{11} \mathrm{H}_{7} \mathrm{ClO}_{4}$ as deduced from the HRMS data. The NMR data of this compound and those of compound 7 were similar with the main difference being the carboxylic acid moiety in compound $\mathbf{8}$. The presence of carboxylic acid moiety in the molecule was established from the molecular formula and the absorption peak at $1695 \mathrm{~cm}^{-1}$ for a carbonyl group and the broad absorption band at $3428 \mathrm{~cm}^{-1}$ for the hydroxyl group in the IR spectra. Because of the NOESY correlation between H-10 and H-9 observed, the side chain double bond was assigned an $E$ - configuration.

\section{Biological activities}

Compounds 1-8, favolon and 2,3 -dihydro-1-benzoxepin derivative were subjected to antimicrobial activity assays against Candida tenuis MUCL29982, Mucor plumbeus MUCL 49355, Escherichia coli DSM498 and Bacillus subtilis DSM10. Strobilurin G and pterulinic acid were not tested due to limited amounts of sample. None of the compounds tested displayed any antibacterial activities at concentrations $\leq 300 \mu \mathrm{g} / \mathrm{mL}$. Compound 1-4 showed strong antifungal activity (table 1). Compound 1 had MIC of $\leq 9.37 \mu \mathrm{g} / \mathrm{mL}$ and $\leq 18.75 \mu \mathrm{g} / \mathrm{mL}$ against $C$. tenuis and M. plumbeus respectively. Compound $\mathbf{2 , 3}$ and $\mathbf{4}$ similarly exhibited activities against the same test organism ranging from $\leq 4.68 \mu \mathrm{g} / \mathrm{mL}$ to $\leq 9.37 \mu \mathrm{g} / \mathrm{mL}$ (Table 2). The strong bioactivity of naturally occurring (E)- $\beta$-methoxyacrylate has been reported before with their activity being attributed to (E)- $\beta$-methoxyacrylate moiety in the molecules which inhibit the mitochondrial respiration (Sauter et al., 1999). 
The isolated compounds generally exhibited lower antifungal activity compared to the other naturally occurring strobilurins reported before (Sauter et al., 1999). Prior work has already indicated that the inhibitory effects of (E)- $\beta$-methoxyacrylate are dependent on the substituents at C-9, specifically the oxygen substituents at C-9 tend to reduce the bioactivity of this class of compounds (Engler et al., 1999). Favolon, which had previously been reported by Anke et al. (1995) to be a potent antifungal agent as expected, exhibited strong antifungal activity with MIC

of $2.34 \mu \mathrm{g} / \mathrm{mL} .2,3$-dihydro-1-benzoxepin derivative did not show any antifungal activity. Most of the compounds exhibited significant but moderate cytotoxicity against mouse fibroblasts and HeLa cell lines. Compound 1-4 displayed moderate cytotoxicity against both cell lines tested ( $\mathrm{IC}_{50} 1.1-18 \mu \mathrm{g} / \mathrm{mL}$ ). Compounds 6, 7 and 2,3-dihydro-1-benzoxepin derivative were inactive against mouse fibroblasts cell lines but were active against $\mathrm{HeLa}$ with $\mathrm{IC}_{50}$ of $0.3,5.8$ and 18 $\mu \mathrm{g} / \mathrm{mL}$ respectively. Compounds 5 and $\mathbf{8}$ showed $\mathrm{IC}_{50}$ values of 28 and $1.7 \mu \mathrm{g} / \mathrm{mL}$ for compound 5 and $32 \mu \mathrm{g} / \mathrm{mL}$ and $10 \mu \mathrm{g} / \mathrm{mL}$ for compound 8 against mouse fibroblast and HeLa cell lines respectively. Favolon was not tested for cytotoxicity but the lack of cytotoxicity against L210 cells (mouse lymphocytic leukemia ATCC CCL 219) had been reported before (Anke et al., 1995).

\section{Conclusions}

In conclusion, four previously undescribed strobilurin derivatives (1-4) with a keto group at position 9 and monochlorinated calocerins A-D (5-8) were isolated from Favolaschia calocera fermented mycelium culture. The strobilurins as expected showed selective antifungal activity. All the compounds isolated also showed weak to moderate cytotoxicity activity against mouse fibroblasts and HeLa cell lines. Strobilurins are an important class of compounds from Basidiomycota that have served as lead compounds for the development of the agricultural ß- 
methoxyacrylate fungicides (Sauter et al., 1999). These compounds have been isolated from the mycelial cultures of various fungal strains including Favolaschia, Mycena, Oudemansiella, Xerula and Strobilurus (Stadler and Hoffmeister, 2015). From the genus Favolaschia in particular, several bioactive compounds compounds like laschiatrion and favolon have been reported previously (Anke et al., 2004, 1995; Sauter et al., 1999). Favolaschia calocera is actually not rare but is even regarded as an invasive species that probably originates from Africa, but has been introduced to Australia, New Zealand and more recently, even Europe (Vizzini et al., 2009). The ability of this species to produce several types of antifungal antibiotics simultaneously and to colonize various kinds of substrates may be one of the reasons for its ecological success.

\section{Experimental Section}

\subsection{General experimental procedure}

Optical rotations were determined with a Perkin-Elmer 241 spectrometer; IR spectra were measured with a Spectrum 100 FTIR spectrometer (Perkin-Elmer), UV spectra were recorded with a Shimadzu UV-vis spectrophotometer UV-2450. NMR spectra were recorded with Bruker Ascend 700 spectrometer with 5mm TXI cryoprobe $\left({ }^{1} \mathrm{H} 700 \mathrm{MHz},{ }^{13} \mathrm{C} 175 \mathrm{MHz}\right)$ and Bruker AV

II-600 ( $\left.{ }^{1} \mathrm{H} 500 \mathrm{MHz},{ }^{13} \mathrm{C} 150 \mathrm{MHz}\right)$ spectrometers. HR-ESI-MS mass spectra were recorded with Agilent 1200 series HPLC-UV system (column 2.1 x 50 mm, $1.7 \mu \mathrm{m}, \mathrm{C} 18$ Acquity UPLC BEH (waters), solvent $\mathrm{A}: \mathrm{H}_{2} \mathrm{O}+0.1 \%$ formic acid; solvent $\mathrm{B}$ : $\mathrm{AcCN}+0.1 \%$ formic acid, gradient: $5 \%$ B for 0.5 minutes increasing to $100 \%$ B in 19.5 minutes and then maintaining $100 \%$ B for 5

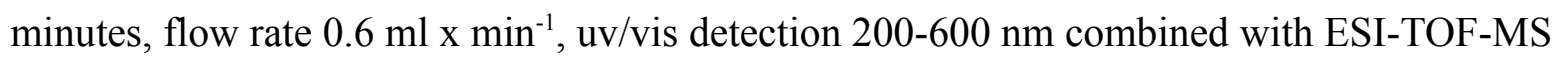
(Maxis, Brucker) [scan range $100-2500 \mathrm{~m} / \mathrm{z}$, capillary voltage $4500 \mathrm{~V}$, dry temperature $200^{\circ} \mathrm{C}$ ]. 
4.2 Fungal material. The fungal strain Favolaschia calocera R. Heim (Mycenaceae) was

collected by M. S. and J. C. M. from Kakamega equatorial rainforest, located in the western part of Kenya $\left(0^{\circ} 17^{\prime} 3.19^{\prime \prime} \mathrm{N} 34^{\circ} 45^{\prime} 8.24^{\prime \prime} \mathrm{E}\right)$ in August of 2013. The dried herbarium specimen was deposited at Egerton University with the code STMA 13419. The culture was isolated from spore prints and grown on $\mathrm{YMG}$ agar plates and is maintained at $-80^{\circ}$ in the culture collection of the HZI, Braunschweig, Germany.

The fungus was identified by morphological studies and by sequencing of the rDNA ( $5.8 \mathrm{~S}$ gene region, internal transcribed spacer ITS1 and ITS2) and part of the large subunit LSU as described previously (Mudalungu et al., 2016). These sequence data are deposited in GenBank with accession number KX447791.

DNA extraction was performed with the EZ-10 Spin Column Genomic DNA Miniprep kit (Bio Basic Canada Inc., Markham, Ontario, Canada). A Precellys 24 homogenizer (Bertin Technologies, France) was used for cell disruption at a speed of $6000 \mathrm{rpm}$ for $2 \times 40 \mathrm{~s}$. The gene regions were amplified with primers ITS 1f and NL4.

4.3 Small scale fermentation. F. calocera strain STMA 13419 was cultivated in three different liquid media (YMG: $10 \mathrm{~g} / \mathrm{ml}$ malt extract, $4 \mathrm{~g} / \mathrm{mL}$ yeast extract, $4 \mathrm{~g} / \mathrm{mL}$ D-glucose and $\mathrm{pH}=6.3$; Q6 $1 / 2$ medium: $10 \mathrm{~g} / \mathrm{mL}$ glycerol, $2.5 \mathrm{~g} / \mathrm{ml}$ D- glucose, $5 \mathrm{~g} / \mathrm{Ml}$ cotton seed flour and $\mathrm{pH}=7.2$; ZM1 $/ 2$ medium: $5 \mathrm{~g} / \mathrm{mL}$ molasses , $5 \mathrm{~g} / \mathrm{mL}$ oatmeal, $1.5 \mathrm{~g} / \mathrm{mL}$ D-glucose, $4 \mathrm{~g} / \mathrm{ml}$ sucrose, $4 \mathrm{~g} / \mathrm{mL}$ mannitol, $0.5 \mathrm{~g} / \mathrm{mL}$ edamine, ammonium sulphate $0.5 \mathrm{~g} / \mathrm{mL}, 1.5 \mathrm{~g} / \mathrm{mL}$ calcium carbonate and $\mathrm{pH}=7.2$ ). These three media were selected because previous studies had revealed that they were optimal for attaining complementary secondary metabolites profiles in filamentous fungi (Bitzer et al., 2008). A well grown F. calocera culture grown on an YMG agar plate (YMG supplemented with $1.5 \%$ agar, $\mathrm{pH}=6.3$ ) was cut into small pieces using a cork borer $(7 \mathrm{~mm})$ and 
five pieces inoculated in a batch of ten $500 \mathrm{ml}$ Erlenmeyer flask containing $200 \mathrm{~mL}$ of the three media. The cultures were incubated at $23{ }^{\circ} \mathrm{C}$ on a rotary shaker $(140 \mathrm{rpm})$. The growth of the fungus was monitored by constantly checking the amount of free glucose (using Bayer Diastix Harnzuckerstreifen). The fermentation was terminated two days after glucose depletion. 4.4 Large scale fermentation. Preliminary results suggested that similar metabolite profiles were obtained in all three media but the fungus grew and produced best in YMG medium. Therefore, this medium was selected for scale-up. As seed culture, an YMG shake culture was prepared as described above and grown in a $500 \mathrm{ml}$ Erlenmeyer flask containing $200 \mathrm{ml}$ of YMG medium as the primary culture. The culture was incubated at $23{ }^{\circ} \mathrm{C}$ on a rotary shaker $(140 \mathrm{rpm})$ for 14 days. $15 \mathrm{ml}$ of the primary culture were transferred into $10 \times 1000 \mathrm{~mL}$ Erlenmeyer flask containing $500 \mathrm{ml}$ of YMG medium. The cultures were incubated for further 21 days at $25^{\circ} \mathrm{C}$ on a rotary shaker $(140 \mathrm{rpm})$. Fermentation was aborted 2 days after the depletion of free glucose. 4.5 Extraction of the crude extracts: The supernatant and the mycelia from the small scale fermentation were separated by filtration. The supernatant was extracted with equal amount of ethyl acetate and filtered through anhydrous sodium sulphate. The resulting ethyl acetate extract was evaporated to dryness by means of rotary evaporator. The mycelia were extracted with 200 $\mathrm{mL}$ of acetone in ultrasonic bath for 30 minutes, filtered and the filtrate evaporated. The remaining water phase was suspended in equal amount of distilled water, extracted with equal amount of ethyl acetate and filtered through anhydrous sodium sulphate and the resulting ethyl acetate extract evaporated to dryness.

The mycelia and supernatant from the large scale fermentation were separated via vacuum filtration. The mycelia were extracted with 4 x $500 \mathrm{~mL}$ of acetone in ultrasonic bath for 30 minutes. The extracts were combined and the solvent evaporated by means by rotary evaporator. 
The remaining water phase was suspended in $200 \mathrm{~mL}$ distilled water, extracted with 3 x $500 \mathrm{~mL}$ ethyl acetate and filtered through anhydrous sodium sulphate. The resulting ethyl acetate extract was evaporated to dryness, leaving behind a dark brown solid (1.2 g). The supernatant on the other hand was mixed with $100 \mathrm{~g}$ adsorbent resin (Amberlite $\mathrm{XAD}^{\mathrm{TM}}-16 \mathrm{~N}$ ) and incubated overnight on a shaker. The Amberlite resin was then filtered and eluted with 4 x $500 \mathrm{~mL}$ methanol. The resulting methanol extract were evaporated and the remaining water phase subjected to the same procedure as the acetone water phase of the mycelia. $900 \mathrm{mg}$ dark brown crude extract was obtained.

4.6 Isolation: The bioactive compounds were identified by means of bioassay-guided fractionation. The mycelia and supernatant crude extract was fractionated using preparative reverse phase liquid chromatography (PLC 2020, Gilson, Miiddleton, USA). VP Nucleodur 1005 C 18 ec column ( 250 x 40, $7 \mu \mathrm{m}$ : Macherey-Nagel) used as stationary phase. Deionized water (Milli-Q, Millipore, Schwalbach, Germany) with $0.05 \%$ TFA (solvent A) and acetonitrile with $0.05 \%$ TFA (solvent B) were used as the mobile phase. Elution gradient used was 5- 100\% solvent B in 60 minutes and thereafter isocratic condition at 100\% solvent B for 5 minutes. UV detection was carried out at 210,254 and $350 \mathrm{~nm}$. Ten fractions were collected according to the observed peaks (F-1 - F-10) for the mycelial extract and 15 fractions (F1-F15) for the supernatant extract. For detailed procedure on purification of fractions see SI.

4.7 Bioactivity assay: Minimum Inhibitory Concentrations (MIC) were determined in serial dilution assays as described previously by Halecker et al. (2014) and Okanya et al. (2011) using different test microorganisms. The assays were carried out in 96-well microtiter plates in YMG medium for filamentous fungi and yeasts and EBS medium ( $0.5 \%$ casein peptone, $0.5 \%$ glucose, $0.1 \%$ meat extract, $0.1 \%$ yeast extract, $50 \mathrm{mM}$ HEPES $[11.9 \mathrm{~g} / \mathrm{L}]$ and $\mathrm{pH}=7.0$ ) for bacteria. For 
the small scale fermentation extracts and pure compounds, the starting concentration was $300 \mu \mathrm{g} / \mathrm{mL}$.

4.8 Cytotoxicity assays: The in vitro cytotoxicity assay with mouse fibroblasts cell line L929 and $\mathrm{HeLa}$ (KB3.1) was carried out according to Okanya et al. (2011).

\subsection{Conversion of strobilurin $K$ to strobilurin $I$.}

To a solution of strobilurin $\mathrm{K}(4 \mathrm{mg})$ in $\mathrm{CHCl}_{3}(1 \mathrm{~mL})(0.2 \mathrm{~mL}) 99 \%$ trifluoroacetic acid (TFA) was added and the solution was stirred overnight at $20^{\circ} \mathrm{C}$. The solvent was evaporated under reduced pressure (Hellwig et al., 1999). The residue was purified by reverse phase LC (water/acetonitrile), elution gradient $70-90 \%$ acetonitrile for 30 minutes followed by gradient shift from 90-100 \% acetonitrile in 5 minutes and finally isocratic condition at $100 \%$ acetonitrile for 5 minutes with preparative (orbit) 100 Diol $250 \times 20 \mathrm{~mm} 5 \mu \mathrm{m}$ column as stationary phase. The resulting strobilurin I (2.5 mg) was identified by its ${ }^{1} \mathrm{H}$ NMR and MS data.

\subsection{Conversion of strobilurin I and strobilurin I obtained from strobilurin K to MTPA esters.}

To two portions $(0.75 \mathrm{mg})$ of each compound dissolved in pyridine $(300 \mu \mathrm{L}), 10 \mu \mathrm{L}$ of $(\mathrm{R})$ - and

(S)- MTPA- chloride was added and the reaction mixture kept at room $22{ }^{\circ} \mathrm{C}$ for 4 hours. $\Delta \partial^{\mathrm{SR}}=$ $\partial$ (S-MTPA ester) - $\partial$ (R-MTPA ester) was determined from their ${ }^{1} \mathrm{H}$ NMR.

9-oxostrobulirin A (1): UV $\left(\mathrm{CDCl}_{3}\right) \lambda_{\max }(\log \varepsilon) 289$ (4.676), $246(4.527) .[\alpha]_{\mathrm{D}}^{20}=+16.8^{\circ}$ $(\mathrm{C}=0.00071, \mathrm{MeOH}) . \mathrm{IR}(\mathrm{KBr}) v_{\max } 2945,1709,1635,1607,1443,1408,1314,1253,1237$, 1133, 1034, 765. ${ }^{1} \mathrm{H}$ NMR (700 MHz, chloroform $\left.-d_{1}\right) . \delta 7.52(2 \mathrm{H}, \mathrm{d}, J=9.61 \mathrm{~Hz}, \mathrm{ArH}-1,5), 7.37$ (3H, m, ArH), 7.78 (1H, d, J=16.02 Hz, H-7), 6.78 (1H, d, J=16.02 Hz, H-8), 3.83 (1H, q, J= $6.87 \mathrm{~Hz}, \mathrm{H}-10), 7.42$ (1H, s, H-12), 1.30 (3H, d, J=6.87 Hz, H-14), 3.85 (3H, s, H-15), 3.73 (3H, s, H-16). 
${ }^{13} \mathrm{C}$ NMR (175MHz, chloroform- $d_{1}$ ) $\delta 128.2$ (C-1,5), 128.7 (C-2,4), 130.1 (C-3), 134.9 (C-6), 141.3 (C-7), 123.8 (C-8), 198.9 (C-9), 42.4 (C-10), 110.8 (C-11), 160.2 (C-12), 167.8 (C-13), 13.7 C-14), 61.8 (C-15), 51.5 (C-16). HR-MS m/z $275.127[\mathrm{M}+\mathrm{H}]^{+}$calcd for $\mathrm{C}_{16} \mathrm{H}_{18} \mathrm{O}_{4}, 274.311$. 9-oxostrobilurin G (2): $\mathrm{UV}\left(\mathrm{CDCl}_{3}\right) \lambda_{\max }(\log \varepsilon) 202$ (4.937), $238(4.879), 313(4.75) \mathrm{nm} .[\alpha]_{\mathrm{D}}^{20}$ $=+60^{\circ}(0.002, \mathrm{MeOH}) . \mathrm{IR}(\mathrm{KBr}) v_{\max } 3450,2978,2928,1706,1640,1570,1421,1262,1240$, 1130, 1031, 984, 825, 770. ${ }^{1} \mathrm{H}$ NMR (700 MHz, chloroform - $\left.d_{l}\right) \delta 7.11(1 \mathrm{H}, \mathrm{d}, \mathrm{J}=1.94 \mathrm{~Hz}, \mathrm{H}-1)$, $6.91(1 \mathrm{H}, \mathrm{d}, \mathrm{J}=8.17 \mathrm{~Hz}, \mathrm{H}-4), 7.15(1 \mathrm{H}, \mathrm{dd} \mathrm{J}=1.94,11.62 \mathrm{~Hz}, \mathrm{H}-5), 7.47(1 \mathrm{H}, \mathrm{d}, \mathrm{J}=15.92 \mathrm{~Hz}, \mathrm{H}-$ 7), $6.64(1 \mathrm{H}, \mathrm{d}, \mathrm{J}=15.92 \mathrm{~Hz}, \mathrm{H}-8), 3.79(1 \mathrm{H}, \mathrm{q}, \mathrm{J}=6.88, \mathrm{H}-10), 7.41$ (1H, s, H-12), 1.29, (3H, d, $\mathrm{J}=6.88 \mathrm{~Hz}, \mathrm{H}-14), 3.85$ (3H, s, H-15), 3.72 (3H, s, H-16), 4.05 (1H, dd, J=7.48, $12.51 \mathrm{~Hz}$, Ha18), 4.28, (1H, dd, J=3.05, $12.51 \mathrm{~Hz}, \mathrm{Hb}-18), 3.53$ (1H, dd, J=3.01, $8.39 \mathrm{~Hz}, \mathrm{H}-19), 1.26$ (3H, s, H-21), 1.47 (3H, s, H-22), 4.07 (1H, J= 6.88, $11.83 \mathrm{~Hz}, \mathrm{Ha}-23), 4.15(1 \mathrm{H}, \mathrm{J}=6.88 \mathrm{~Hz}, 11.83$, dd, Hb-23), 5.35 (1H, brt, J= 6.88 Hz, H-24), 1.70 (3H, s, H-26), 1.77 (3H,s, H-27).

${ }^{13} \mathrm{C}$ NMR (175MHz, chloroform- $\left.d_{1}\right) \delta 123.7$ (C-1), 146.6 (C-2), 153.0 (C-3), 120.8 (C-4), 124.7 (C-5), 130.4 (C-6), 140.6 (C-7), 122.6 (C-8), 198.8 (C-9), 42.4 (C-10), 110.9 (C-11), 160.2 (C12), 167.8 (C-13), 13.8 C-14), 61.8 (C-15), 51.5 (C-16), 68.8 (C-18), 81.7 (C-19), 81.2 (C-20), 20.9 (C-21), 27.5 (C-22), 67.3 (C-23), 120.7 (C-24), 137.6 (C-25), 18.1 (C-26), 25.7 (C-27). HRMS m/z 459.2377 $[\mathrm{M}+\mathrm{H}]^{+}$calcd for $\mathrm{C}_{26} \mathrm{H}_{34} \mathrm{O}_{7}, 458.544$.

9-oxostrobilurin K (3): Yellow oil. UV (CDCl $) \lambda_{\max }(\log \varepsilon) 242(4.310), 321(4.246) \mathrm{nm} .[\alpha]_{\mathrm{D}}^{20}$ $=+8.63^{\circ}\left(0.003124, \mathrm{CH}_{3} \mathrm{Cl}\right) . \mathrm{IR}(\mathrm{KBr}) V \max 3439,2989,2928,1706,1602,1497,1259,1135$, 927, 820, 771. 1H NMR (500 MHz, chloroform - $\left.d_{1}\right) \delta 7.09(1 \mathrm{H}, \mathrm{d}, J=2.14 \mathrm{~Hz}, 1-\mathrm{H}), 6.86(1 \mathrm{H}, \mathrm{d}$, $\mathrm{J}=8.09 \mathrm{~Hz}, \mathrm{H}-4), 7.09$ (1H, dd, J=2.14, $8.09 \mathrm{~Hz}, \mathrm{H}-5), 7.44(1 \mathrm{H}, \mathrm{d}, \mathrm{J}=15.87 \mathrm{~Hz}, \mathrm{H}-7), 6.63(1 \mathrm{H}$, d, J=15.87 Hz, H-8), $3.78(1 \mathrm{H}, \mathrm{q}, \mathrm{J}=6.71 \mathrm{~Hz}, \mathrm{H}-10), 7.40(1 \mathrm{H}, \mathrm{s}, \mathrm{H}-12), 1.28(3 \mathrm{H}, \mathrm{d}, \mathrm{J}=6.71 \mathrm{~Hz}$, H-14), 3.83 (3H,s, H-15), 3.71 (3H, s, H-16), 4.08 (1H, dd, J=12.36, 7.48 Hz, H-18a), 4.28 (1H, 
dd, J=12.36, 3.36 Hz, H-18b), 3.68 (1H, dd, J=3.36, 7.48 Hz, H-19), 1.25 (3H, s, H-21), 1.41 (3H, s, H-22), $5.86(1 \mathrm{H}, \mathrm{d}, \mathrm{J}=12.21 \mathrm{~Hz}, \mathrm{H}-24), 5.16$ (2H, d, J=12.21 Hz, H-25), 1.31, (3H, s, H26).

${ }^{13} \mathrm{C}$ NMR (150 MHz, chloroform- $\left.d_{1}\right) \delta 124.6$ (C-1), 146.2 (C-2), 152.8 (C-3), 120.3 (C-4), 123.4 (C-5), 129.9 (C-6), 140.6 (C-7), 122.4 (C-8), 198.7 (C-9), 42.3 (C-10), 110.9 (C-11), 160.2 (C12), 167.8 (C-13), 13.8 (C-14), 61.8 (C-15), 51.4 (C-16), 71.9 (C-18), 75.3 (C-19), 82.2 (C-20), 22.2 (C-21), 27.9 (C-22), 76.2 (C-23), 143.3 (C-24), 114.5 (C-25), 26.2 (C-26). HR-MS m/z $459.2380[\mathrm{M}+\mathrm{H}]^{+}$calcd for $\mathrm{C}_{26} \mathrm{H}_{34} \mathrm{O}_{7}, 458.544$.

9-oxostrobilurin I (4): yellow oil. UV ( $\left.\mathrm{CDCl}_{3}\right) \lambda_{\max }(\log \varepsilon) 201$ (4.234), 238 (4.4249), 310 (4.135) nm. $[\alpha]_{\mathrm{D}}{ }^{20}=+23.70^{\circ}(0.002, \mathrm{MeOH}) . \mathrm{IR}(\mathrm{KBr}) V_{\max } 3450,2972,2928,1703,1640,1503$, 1259, 1133, 1034, 980, 821, 770. ${ }^{1} \mathrm{H}$ NMR $\left(700 \mathrm{MHz}\right.$, chloroform $\left.-d_{1}\right) \delta 7.17(1 \mathrm{H}, \mathrm{d}, \mathrm{J}=2.29 \mathrm{~Hz}$, H-1), 6.99 (1H, d, J=8.24, H-4), 7.15 (1H, dd J=2.29, $13.43 \mathrm{~Hz}, \mathrm{H}-5), 7.49(1 \mathrm{H}, \mathrm{d}, \mathrm{J}=15.87 \mathrm{~Hz}$, H-7), 6.65 (1H, d, J=15.87, H-8), 3.79 (1H, q, J=6.87 Hz, H-10), 7.42 (1H, s, H-12), 1.30, (3H, d, J=6.87 Hz, H-14), 3.86 (3H, s, H-15), 3.73 (3H, s, H-16), 4.13 (1H, dd, J= 7.17, 12.66 Hz, Ha18), $4.21(1 \mathrm{H}, \mathrm{dd}, \mathrm{J}=2.75,12.66 \mathrm{~Hz}, \mathrm{Hb}-18), 3.63(1 \mathrm{H}, \mathrm{dd}, \mathrm{J}=2.75,7.17 \mathrm{~Hz}, \mathrm{H}-19), 1.25$ (3H, s, H-21), 1.54 (3H, s, H-22).

${ }^{13} \mathrm{C}$ NMR (175MHz, chloroform- $d_{1}$ ) $\delta 123.4$ (C-1), 147.9 (C-2), 153.7 (C-3), 121.9 (C-4), 124.8 (C-5), 131.5 (C-6), 140.2 (C-7), 123.1 (C-8), 198.7 (C-9), 42.4 (C-10), 110.8 (C-11), 160.3 (C12), 167.8 (C-13), 13.8 C-14), 61.8 (C-15), 51.5 (C-16), 70.9 (C-18), 75.3 (C-19), 81.5 (C-20), 23.8 (C-21), 25.8 (C-22). HR-MS m/z $391.1751[\mathrm{M}+\mathrm{H}]^{+}$calcd for $\mathrm{C}_{21} \mathrm{H}_{26} \mathrm{O}_{7}, 390.427$.

\section{(S)- MTPA ester obtained from strobilurin I}


${ }^{1} \mathrm{H}$ NMR (700 MHz, Pyridine- $\left.d_{5}\right) \delta 1.38(3 \mathrm{H}, \mathrm{s}), 1.42(3 \mathrm{H}, \mathrm{s}), 1.56(3 \mathrm{H}, \mathrm{s}, J=6.88 \mathrm{~Hz}), 3.57(3 \mathrm{H}$, s), $3.65(3 \mathrm{H}, \mathrm{s}), 3.68(3 \mathrm{H}, \mathrm{s}),, 4.10(1 \mathrm{H}, \mathrm{q}, J=6.88 \mathrm{~Hz}), 4.41(1 \mathrm{H}, \mathrm{dd}, J=4.95,13.34 \mathrm{~Hz}), 4.50$ $(1 \mathrm{H}, \mathrm{dd}, J=2.37,13.34 \mathrm{~Hz}), 5.49(1 \mathrm{H}, \mathrm{dd}, J=2.37,4.95), 6.97(1 \mathrm{H}, \mathrm{d}, J=8.17 \mathrm{~Hz}, 7.15(1 \mathrm{H}, \mathrm{d}, J=$ $15.70 \mathrm{~Hz}), 7.44(5 \mathrm{H}, \mathrm{m}), 7.46(1 \mathrm{H}, \mathrm{d}, J=2.58 \mathrm{~Hz}), 7.62(1 \mathrm{H}, \mathrm{s}), 7.78(1 \mathrm{H}, \mathrm{dd}, J=2.58,8.17 \mathrm{~Hz})$, $7.84(1 \mathrm{H}, \mathrm{d}, \mathrm{J}=15.70)$. HR-MS m/z=607.2150, 606.5835 calcd. for $\mathrm{C}_{31} \mathrm{H}_{33} \mathrm{~F}_{3} \mathrm{O}_{9}$.

\section{(R)- MTPA ester obtained from strobilurin I}

${ }^{1} \mathrm{H}$ NMR (700 MHz, Pyridine- $\left.d_{5}\right) \delta 1.25(3 \mathrm{H}, \mathrm{s}), 1.31(3 \mathrm{H}, \mathrm{s}), 1.56(3 \mathrm{H}, \mathrm{s}, J=6.88 \mathrm{~Hz}), 3.57(3 \mathrm{H}$, s), $3.65(3 \mathrm{H}, \mathrm{s}), 3.68(3 \mathrm{H}, \mathrm{s}), 4.10(1 \mathrm{H}, \mathrm{q}, J=6.88 \mathrm{~Hz}), 4.53(1 \mathrm{H}, \mathrm{dd}, J=4.30,13.55 \mathrm{~Hz}), 4.52$ $(1 \mathrm{H}, \mathrm{dd}, J=2.15,13.55 \mathrm{~Hz}), 5.48(1 \mathrm{H}, \mathrm{dd}, J=2.15,4.30), 7.06(1 \mathrm{H}, \mathrm{d}, J=8.17 \mathrm{~Hz}, 7.15(1 \mathrm{H}, \mathrm{d}, J=$ $15.92 \mathrm{~Hz}), 7.43(5 \mathrm{H}, \mathrm{m}), 7.40(1 \mathrm{H}, \mathrm{d}, J=2.15 \mathrm{~Hz}), 7.62(1 \mathrm{H}, \mathrm{s}), 7.81(1 \mathrm{H}, \mathrm{dd}, J=2.15,8.17 \mathrm{~Hz})$, 7.84 (1H, d, J=15.92). HR-MS: $\mathrm{m} / \mathrm{z}=607.2142,606.5835$ calcd. for $\mathrm{C}_{31} \mathrm{H}_{33} \mathrm{~F}_{3} \mathrm{O}_{9}$.

Calocerin A (5): White solid. UV ( $\left.\mathrm{CDCl}_{3}\right) \lambda_{\max }(\log \varepsilon) 293$ (4.272), 244 (4.341), 206 (3.978) nm. IR (KBr) $V_{\max } 3368,3181,2917,1651,1613,1430,1390,1174,919,806,792 .{ }^{1} \mathrm{H}$ NMR $(500$ $\mathrm{MHz}$, chloroform $\left.-d_{1}\right) \delta 7.41(1 \mathrm{H}, \mathrm{s}, \mathrm{H}-3), 8.11(1 \mathrm{H}, \mathrm{s}, \mathrm{H}-4), 7.80(1 \mathrm{H}, \mathrm{dd}, J=1.83,8.54 \mathrm{~Hz}, \mathrm{H}-$ 6), $7.54(1 \mathrm{H}, \mathrm{d}, J=8.54 \mathrm{~Hz}, \mathrm{H}-7), 2.25$ (3H, s, H-9), 6.27 (1H, s, H-11).

${ }^{13} \mathrm{C}$ NMR (150MHz, chloroform - $\left.d_{1}\right) \delta 154.2$ (C-2), $107.6(\mathrm{C}-3), 128.7$ (C-3a), $121.2(\mathrm{C}-4)$, 128.4 (C-5), 124.3 (C-6), 111.2 (C-7), 155.5 (C-7a), 127.0 (C-8), 19.4 (C-9), 169.5 (C-10), 115.7 (C-11). HR-MS m/z 236.0466 [M+H $]^{+}$calcd for $\mathrm{C}_{12} \mathrm{H}_{10} \mathrm{ClNO}_{2}$, 235.663. Cl-35

Calocerin B (6): White solid. UV ( $\left.\mathrm{CDCl}_{3}\right) \lambda_{\max }(\log \varepsilon) 205$ (4.149), 238 (4.324), 280 (4.304), 288 (4.336), 301 (4.222) nm. IR (KBr) $V_{\max } 3373,3175,2919,1651,1607,1434,1388,1173,921$, 825,795. ${ }^{1} \mathrm{H}$ NMR $\left(500 \mathrm{MHz}\right.$, methanol $\left.-d_{4}\right) \delta 6.95(1 \mathrm{H}, \mathrm{s}, \mathrm{H}-3), 8.31(1 \mathrm{H}, \mathrm{s}, \mathrm{H}-4), 7.85$ (1H, dd, $J=1.98,8.70 \mathrm{~Hz}, \mathrm{H}-6), 7.54(1 \mathrm{H}, \mathrm{d}, J=8.70 \mathrm{~Hz}, \mathrm{H}-7), 2.20(3 \mathrm{H}, \mathrm{s}, \mathrm{H}-9), 7.04$ (1H, s, 1H-11). 
${ }^{13} \mathrm{C}$ NMR (150MHz, methanol- $\left.d_{4}\right) \delta 157.6$ (C-2), 104.9 (C-3), 130.1 (C-3a), 122.5 (C-4), 130.4 (C-5), 126.1 (C-6), 111.8 (C-7), 158.1 (C-7a), 129.2 (C-8), 14.0 (C-9), 172.5 (C-10), 119.8 (C11). HR-MS m/z $236.0513[\mathrm{M}+\mathrm{H}]^{+}$, calcd for $\mathrm{C}_{12} \mathrm{H}_{10} \mathrm{ClNO}_{2}$ 235.663. Cl-35

Calocerin C (7): White solid. UV ( $\left.\mathrm{CDCl}_{3}, \mathrm{c}=0.0125\right) \lambda_{\max }(\log \varepsilon) 275(3.995), 241(4.425) \mathrm{nm}$. IR (KBr) $V_{\max } 3351,3181,2923,1651,1407,1209,1133,1113,1042,1037,779,661 .{ }^{1} \mathrm{H}$ NMR $\left(700 \mathrm{MHz}\right.$ chloroform $\left.-d_{1}\right) \delta 5.72(1 \mathrm{H}, \mathrm{d}, J=7.53 \mathrm{~Hz}, \mathrm{H}-5), 5.75(1 \mathrm{H}, \mathrm{s}, \mathrm{H}-10), 6.54(1 \mathrm{H}, \mathrm{d}, J=$ $7.53 \mathrm{~Hz}, \mathrm{H}-4), 7.703$ (1H, d, J=2.37, H-6), $7.36(1 \mathrm{H}, \mathrm{d}, \mathrm{J}=8.39 \mathrm{~Hz}, \mathrm{H}-9), 7.64$ (1H, dd, J=2.37, $8.39 \mathrm{~Hz}, \mathrm{H}-8)$.

${ }^{13} \mathrm{C}$ NMR (175 MHz chloroform - $d_{1}$ ) $\delta 152.9$ (C-2), 142.2 C-4, 105.1 (C-5), 126.1 (C-5a), 129.2 (C-6), 130.2 (C-7), 126.7 (C-8), 120.3 (C-9), 94.1 (C-10), 168.1 (C-11). HR-MS: m/z 238.0262[M+H $]^{+}$calcd for $\mathrm{C}_{11} \mathrm{H}_{8} \mathrm{ClNO}_{3}$ 237.63912. $\mathrm{Cl}-35$

Calocerin D (8): White solid. UV (MeOH, c= 0.0125) $\lambda_{\max }(\log \varepsilon) 274(3.470), 237(3.873) \mathrm{nm}$. IR (KBr) $V_{\max } 3428,3098,2923,2565,1695,1670,1412,1283,1196,1144,1119,1050,921$, 768. ${ }^{1} \mathrm{H}$ NMR (700 MHz DMSO) $\delta 6.05(1 \mathrm{H}, \mathrm{d}, J=7.19 \mathrm{~Hz}, \mathrm{H}-6), 6.15(1 \mathrm{H}, \mathrm{s}, \mathrm{H}-10), 6.88(1 \mathrm{H}$, d, J=7.19 Hz, H-4), $7.27(1 \mathrm{H}, \mathrm{d}, \mathrm{J}=8.57 \mathrm{~Hz}, \mathrm{H}-9), 7.85(1 \mathrm{H}, \mathrm{dd}, J=1.94,8.57 \mathrm{~Hz}, \mathrm{H}-8), 7.93$ $(1 \mathrm{H}, \mathrm{d}, \mathrm{J}=1.94 \mathrm{H}-6)$.

${ }^{13} \mathrm{C}$ NMR (175 MHz DMSO) $\delta 152.8$ (C-2), 141.7 (C-4), 105.2 (C-5), 125.2 (C-5a), 131.2 (C-6), 128.3, (C-7), 129.8 (C-8), 119.2 (C-9), 158.2 (C-9a), 93.8 (C-10), 166.3 (C-11). HR-MS m/z 238.0101 $[\mathrm{M}+\mathrm{H}]^{+}$, calcd for $\mathrm{C}_{11} \mathrm{H}_{8} \mathrm{ClNO}_{3}$ 238.6238. Cl-35

\section{Acknowledgements}

We are grateful to W. Collisi for conducting the bioassays and C. Kakoschke and C. Schwager for recording NMR and HPLC-MS data and to Dr. S. Helaly and Dr. Frank Surup for valuable 
scientific discussions. Financial support by the the ASAFEM Project (Grant no. IC-070) under the ERAfrica Programme to J.C.M. and M.S. and a personal PhD stipend German Academic Exchange Service (DAAD) and the Kenya National Council for Science and Technology (NACOSTI) to C.C. is gratefully acknowledged.

\section{References}

Anke, T., Werle, A., Kappe, R., Sterner, O., 2004. Laschiatrion, a new antifungal agent from Favolaschia species (basidiomycetes) active against human pathogens. J. Antibiot. 57, 496-501.

Anke, T., Werle, A., Zapf, S.F., 1995. Favolon, a new antifungal triterpenoid from a Favolaschia species. J. Antibiot. 48, 725-726.

Bitzer, J., Læssøe, T., Fournier, J., Kummer, V., Decock, C., Tichy, H.V., Piepenbring, M., Peršoh, D., Stadler, M., 2008. Affinities of Phylacia and the daldinoid Xylariaceae, inferred from chemotypes of cultures and ribosomal DNA sequences. Mycol. Res. 2008, 112, 251-270.

De Silva, D.D., Rapior, S., Sudarman, E., Stadler, M., Xu, J., Aisyah, S.A., Hyde, K.D., 2013. Bioactive metabolites from macrofungi: ethnopharmacology, biological activities and chemistry. Fungal Divers. 62, $1-40$.

Engler, M., Anke, T., Hellwig, V., Steglich, W.Z., 1999. Noroudemansin A, a new antifungal antibiotic from Pterula species 82168 and three semisynthetic derivatives. Zeitschr. Naturf. 54c, 163-1688.

Engler, M., Anke, T., Sterner, O., 1997 . Pterulinic acid and pterulone, two novel inhibitors of NADH:ubiquinone oxidoreductase (complex I) produced by a Pterula species. II. Physicochemical properties and structure elucidation. J. Antibiot.50, 330-333. 
Fredenhagen, A., Kuhn, A., Peter, H.H., Cuomo, V., Giuliano, U., 1990. Strobilurins F, G and H, three new antifungal metabolites from Bolinea lutea. I. Fermentation, isolation and biological activity. J. Antibiot. 43, 655-660.

Gillian, M.N., Blunt, J.W., Cole, A.L.J., Munro, H.G.M., 1997. Investigation of the New Zealand basidiomycete Favolaschia calocera: Revision of the structures of 9-methoxystrobilurins K and L, strobilurin D, and hydroxystrobilurin D. Tetrahedron 38, 7465-7468.

Halecker, S., Surup, F., Kuhnert, E., Mohr, C., Brock, N., Dickschat,J., Junker, C., Schulz,B., Stadler, M., 2014 . Hymenosetin, a 3-decalinoyltetramic acid antibiotic from cultures of the ash dieback pathogen, Hymenoscyphus pseudoalbidus. Phytochemistry 100, 86-91.

Hawksworth, D.L., 2001. The magnitude of fungal diversity: the 1.5 million species estimate revisited. Mycol. Res. 105, 1422-1432.

Hellwig, V., Dasenbrock, J., Klostermeyer, D., Kroiss, S., Sindlinger, T., Spiteller, P., Steffan, B., Steglich, W., 1999. New benzodioxepin type strobilurins from basidiomycetes. Structural revision and determination of the absolute configuration of strobilurin $\mathrm{D}$ and related $\beta$-methoxyacrylate antibiotics. Tetrahedron 55, 10101-10118.

Hoye, T.R., Jeffrey,C.S., Shao, F., 2007. Mosher ester analysis for the determination of absolute configuration of stereogenic (chiral) carbinol carbons. Nature Protocols 2, 2451-2458.

Kornsakulkarn, J., Thongpanchang, C., Chainoy, R., Choowong, W., Nithithanasilp, S., Thongpanchang, T., 2010. Bioactive metabolites from cultures of Basidiomycete_Favolaschia tonkinensis. J. Nat. Prod. 73, 759-762. 
Mudalungu, C.M., Richter, C., Wittstein, K., Ali Abdalla, M.,Matasyoh, J.C., Stadler, M., Süssmuth, R.D, 2015. Laxitextines A and B, cyathane xylosides from the tropical fungus Laxitextum incrustatum. J Nat Prod.79, 894-898.

Okanya, P.W., Mohr, K.I., Gerth, K., Jansen, R. Müller, R., 20111. Marinoquinolines A-F, Pyrroloquinolines from_Ohtaekwangia kribbensis_(Bacteroidetes) J. Nat. Prod. 74, 603-608.

Richter, C., Helaly, S.E., Thongbai, B., Hyde, K.D., Stadler, S., 2016. Pyristriatins A and B: Pyridinocyathane antibiotics from the basidiomycete Cyathus cf. striatus. J Nat Prod. 79: 1684-1688.

Richter, R., Wittstein, K., Kirk, P.M., Stadler, M., 2015. An assessment of the taxonomy and chemotaxonomy of Ganoderma. Fungal Divers. 71, 1-15.

Sauter, H., Steglich, W., Anke, T., 1999. Strobilurins: Evolution of a new class of active substances. Angew. Chem. Int. Ed. 38, 1328-1349 and references cited therein.

Stadler, M., Hoffmeister, D., 2015. Fungal natural products - the mushroom perspective. Front. Microbiol. 6,127.

Thongbai, B., Rapior, S., Wittstein, K., Hyde, K.D., Stadler, M. 2015. Hericium erinaceus, an amazing medicinal mushroom. Mycol. Prog. 14(91), 1-23.

Vizzini, A., Zotti, M., Mello, A., 2009. Alien fungal species distribution: The study case of Favolaschia calocera. Biological invasions. 11(2), 417-429.

Wittstein, K., Rascher, M., Rupcic, Z., Löwen, E., Winter, B., Köster, R.W., Stadler M 2016. Corallocins A-C, nerve growth and brain-derived neurotrophic factor inducing metabolites from the mushroom Hericium coralloides. J. Nat. Prod. 79, 2264-2269. 
Table 1: Biological activities of compound 1-8, and two other known compounds.

\begin{tabular}{|c|c|c|c|c|}
\hline \multirow[t]{2}{*}{ Compounds } & \multicolumn{2}{|c|}{$\begin{array}{l}\text { Antifungal activity } \\
\qquad(\mu \mathrm{g} / \mathrm{ml})\end{array}$} & \multicolumn{2}{|c|}{$\begin{array}{l}\text { Cytotoxicity-L929 } \\
(\mu \mathrm{g} / \mathrm{mL})\end{array}$} \\
\hline & $\begin{array}{l}\text { Candida } \\
\text { tenuis } \\
\text {-MUCL29892 }\end{array}$ & $\begin{array}{l}\text { Mucor } \\
\text { Plumbeus- } \\
\text { MUCL49355 }\end{array}$ & $\begin{array}{l}\text { Mouse } \\
\text { fibroblast- L929 }\end{array}$ & $\begin{array}{l}\text { HeLa- } \\
(\mathrm{KB} 3.1)\end{array}$ \\
\hline 1 & $\leq 9.37$ & $\leq 18.75$ & 15.00 & 5.50 \\
\hline 2 & $\leq 4.68$ & $\leq 9.37$ & 18.00 & 6.00 \\
\hline 3 & $\leq 4.68$ & $\leq 9.37$ & 0.28 & 0.51 \\
\hline 4 & $\leq 4.68$ & $\leq 9.37$ & 1.10 & 5.50 \\
\hline 5 & - & - & 28.00 & 1.70 \\
\hline 6 & - & - & - & 0.30 \\
\hline 7 & - & - & - & 5.80 \\
\hline 8 & - & - & 32 & 10 \\
\hline $\begin{array}{l}2,3 \text {-dihydro-1- } \\
\text { benzoxepin derivative }\end{array}$ & - & - & - & 18 \\
\hline Favolone & $\leq 2.34$ & $\leq 2.34$ & - & - \\
\hline Nystatin $^{\mathrm{c}}$ & $\leq 2.34$ & $\leq 4.68$ & - & - \\
\hline Epothilone $\mathrm{B}^{\mathrm{c}}$ & - & - & - & 0.00022 \\
\hline Epothilone $\mathrm{A}^{\mathrm{c}}$ & - & - & 0.0038 & - \\
\hline Methanol $^{\mathrm{c}}$ & - & - & - & - \\
\hline
\end{tabular}

[a] No antibacterial activities were observed for all the compounds against E. coli (DSM498) and B. subtilis (DSM10) at concentration $\geq 300 \mu \mathrm{g} / \mathrm{mL}$.

[b] Nystatin- antifungal reference. Epothilone A and B cytotoxicity test references. Methanolnegative control, - no activity. 

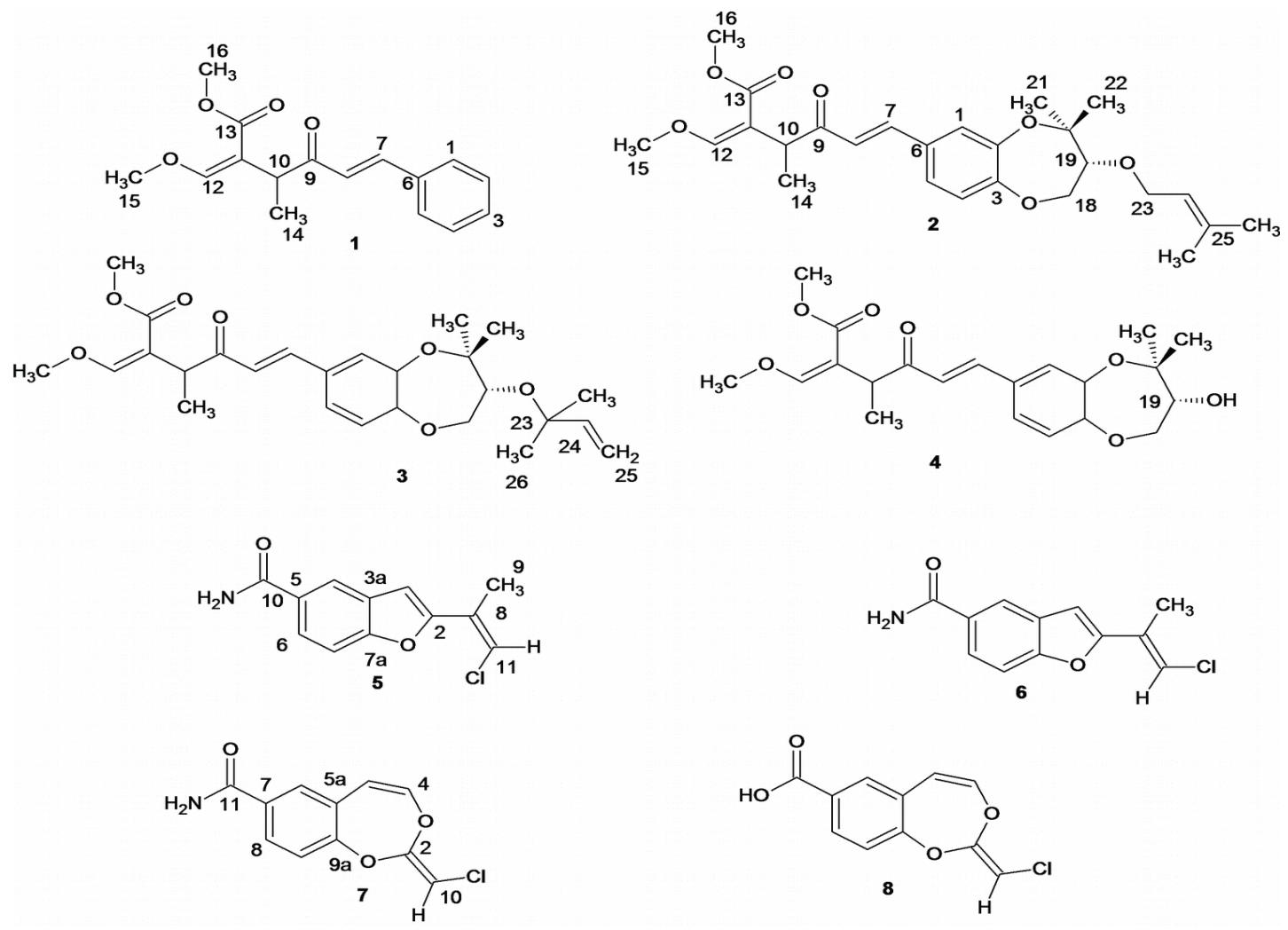

Figure 1. 

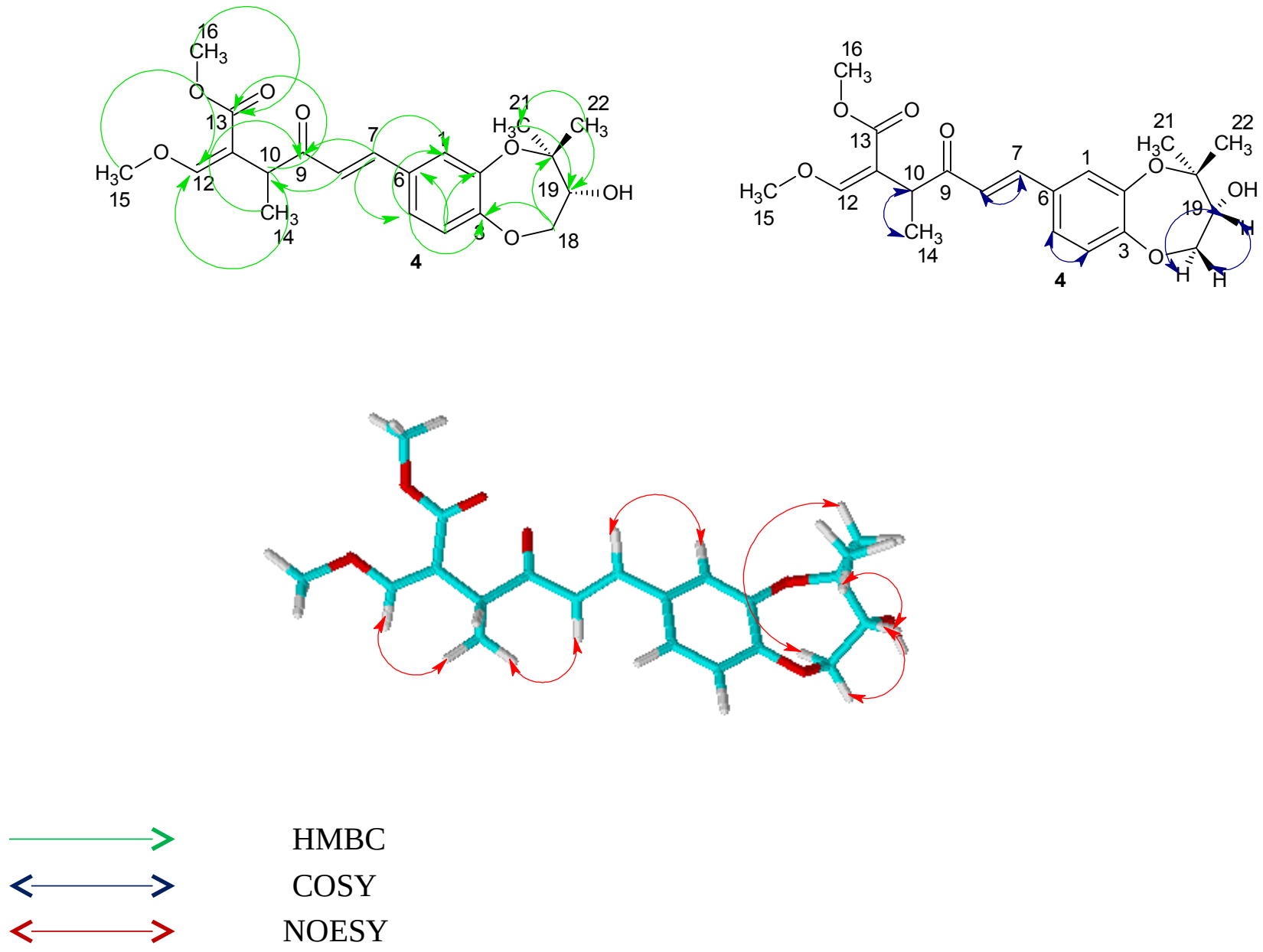

Figure 2. 


\section{Legends to figures}

Figure 1. Structures of compounds 1-8

Figure 2. HMBC, COSY and NOESY correlations of compound 4 